\title{
Walters Farm, Smith County, Texas
}

\section{Mark Walters}

Heritage Research Center, Stephen F. Austin State University

Follow this and additional works at: https://scholarworks.sfasu.edu/ita

Part of the American Material Culture Commons, Archaeological Anthropology Commons, Environmental Studies Commons, Other American Studies Commons, Other Arts and Humanities Commons, Other History of Art, Architecture, and Archaeology Commons, and the United States History Commons

Tell us how this article helped you.

This Article is brought to you for free and open access by the Center for Regional Heritage Research at SFA ScholarWorks. It has been accepted for inclusion in Index of Texas Archaeology: Open Access Gray Literature from the Lone Star State by an authorized editor of SFA ScholarWorks. For more information, please contact cdsscholarworks@sfasu.edu. 


\section{Walters Farm, Smith County, Texas}

Creative Commons License

(c) (i) (8)

This work is licensed under a Creative Commons Attribution-NonCommercial 4.0 International License 


\section{Walters Farm, Smith County, Texas}

\section{Mark Walters}

"I had a farm in Africa," the opening line of the movie Oul of Africa, always reminds me of my little farm in East Texas and what it has meant to me during the 25 years we have been associated. Owning land, particularly when you are relying on it to provide your livelihood, can be a very gratifying (and humbling) experience. Since the land and I are now enjoying a well-deserved rest, I have had time to reflect on our relationship and to wonder how people before me related to the land, especially on these upland settings. Why people choose to settle on any given landscape can be the result of a multitude of factors, environmental as well as social, political, or ideological. I know from scattered remains of tenant houses that my farm was cultivated before me at least back to the mid $-19^{\text {th }}$ century. While I have not conducted any formal archaeological survey of my 300 acres in Smith County, I have been observant as I have wandered around on my place. From time to time, as the surface has been exposed from farming or timber operations, I have noted artifacts indicating the presence of past occupations. I am sure as time goes on I will find other sites on my farm.

Before I try and explain the archaeology on my farm, I think a few words about my 300 acres are in order. Drawing from the Soil Survey of Smith County, Texas (Hatherly 1987), we learn that Smith County is in the central part of northeastern Texas (Figure 1). My farm lies in the eastern portion of the county and drains via Rabbit Creek in a northeasterly direction into the Sabine River, some 20 miles distant. Again according to Hatherly (1987:11-12), the soils in my area are mapped as Bowie-Cuthbert-Kirvin, gently sloping to steep, well-drained loamy soils that have loamy or clayey subsoils. These soils occur on broad inter-stream divides, convex ridge tops, and side slopes above drainages (Figure 2), and were formed under dominantly pine forests. They make up 32 percent of the county. These soils are acidic, often to the point that I had to add lime during my farming operations, and also leading to the poor preservation of plant or animal remains in archaeological sites. But the loamy, well-drained soils are well suited for the production of roses and pine timber, which I have turned to since retiring from commercial rose production.

On my 300 acres the drainage system consists of what are termed first-order streams: those that have no tributaries and are formed by surface runoff, subsurface seepage, and headward erosion of scarps or head-cuts (see Leopold et al. 1963). Incipient gullies, both natural and man-made, make up the bulk of the drainage system on my farm. Stream flow is classified as intermittent with no flow during the two-year drought that we are currently experiencing There are no alluvial settings so characteristic of larger streams with wider valleys in the region. Basically my farm consists of broad uplands intersected by small, mostly dry gullies, that are slowly eating their way up the hills. 


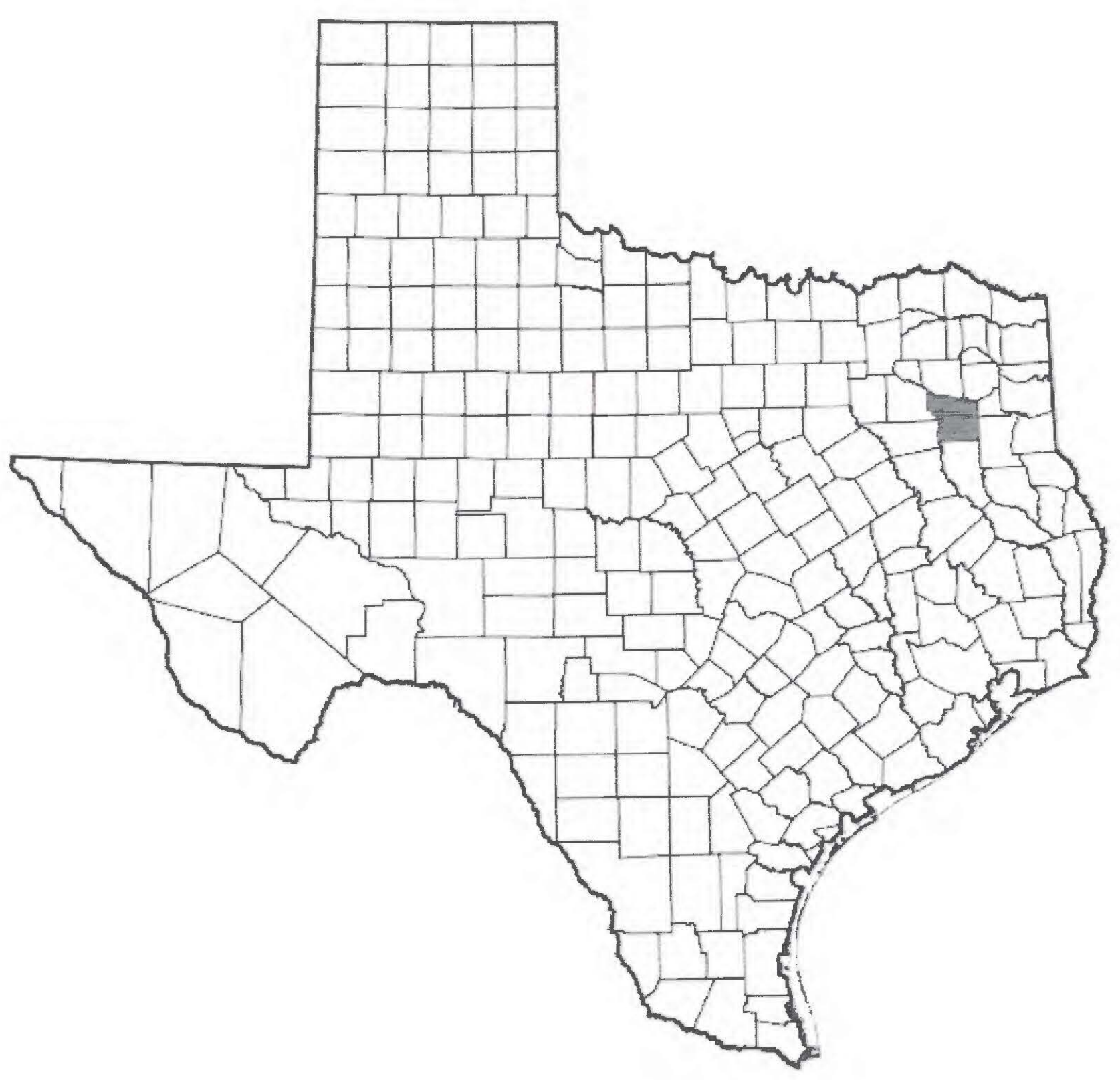

Figure 1. Smith County in the state of Texas. 


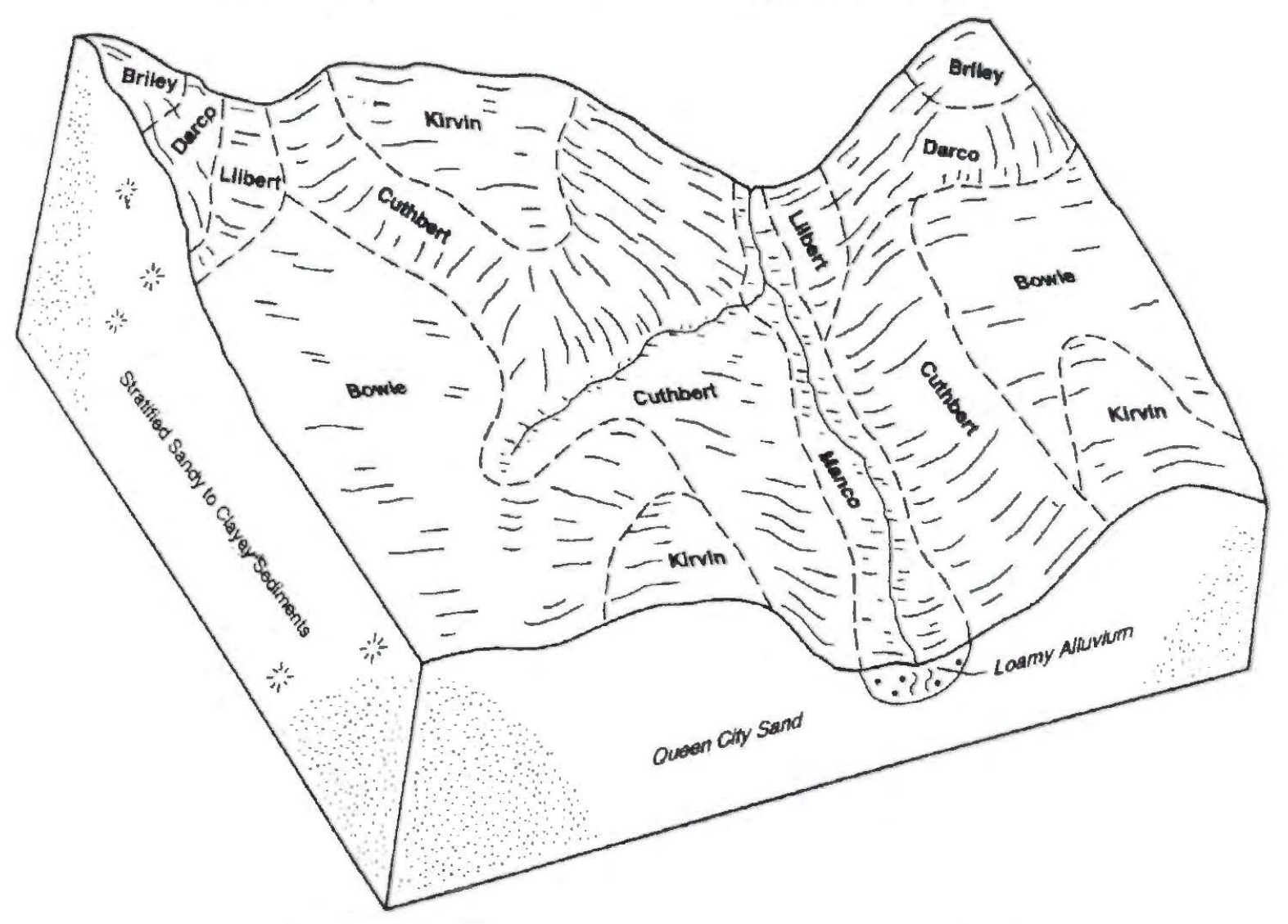

Figure 2. Typical pattern of soils and parent material in the Cuthbert-Bowie-Kirvin general soil map unit (from Hatherly 1987).

As far as the archaeology on the Walters Farm, I would like to draw attention to what I believe was a substantial prehistoric occupation by peoples with a distinctive culture

with a preference for upland settings on the landscape as well as a material culture represented by Williams, Palmillas, and Rice Lobed-like points, made from exotic cherts, and ground stone tools. To distinguish this unique archaeological assemblage I am calling this prehistoric occupation at sites the Browning phase. Browning phase sites are Archaic sites that occur on upland settings usually long distances from water and have a tool kit of large well-made square, expanding, and incurving (or bifurcated) base dart points including numerous examples of Williams, Palmillas, and Rice Lobed-like points. They are made predominately of exotic chert materials. Ground stone tools are found on Browning phase sites. The number of points at some of these locations certainly indicate a major occupation or a series of seasonal occupations.

The Browning phase is similar to, and may be a regional or temporal variation of, the White Oak phase (Schambach 1998:113), part of a highland-oriented Archaic culture characterized by Williams points. Schambach (1998) adds that he had never been able to identify another White Oak phase component (other than the Cooper site) in all his subsequent archaeological work in southwestern Arkansas, all of which has been in the riverine environments of the Gulf Coastal Plain. He also adds that the Cooper site, 
because of its unique position on or near the ecological boundary between the Coastal Plain and the interior uplands, may have played a role as a trade center for the White Oak phase peoples, and thus the presence of Williams points at Cooper (Frank Schambach, 2006 personal communication) Mary Beth Trubitt also makes mention of a similar Middle Archaic period site (3HS195) in the Ouachita River Valley (Trubitt 2005:3-5). Fieldwork there revealed Rice Lobed-like points in association with Williams points, as well as OCR dates that suggest the prehistoric occupation took place about 6000 years ago. The hills of East Texas may have been comparable ecologically to the Ouachita River uplands, enough so to attract this distinctive culture.

Story et al. (1990) describe the Fast Texas area as having prehistoric artifact chronologies similar to those established in the Ouachita-Ozark highlands and Arkansas River basin. Though similar in several ways, she notes that dart points in the northcastern part of the study area are "generally smaller, usually thinner and/or narrower" (Story et al. 1990: 217-222). This distinction does not seem to hold true for the Browning phase points. There also seems to a poor understanding of where Williams and Palmillas points fall in the local East Texas artifact chronologies and there is also a good deal of variation in the identification of the point types. However, it is thought to bc the case that they postdate the Carrollton and Bulverde types and predate the Yarbrough, Trinity, and other apparently Late Archaic dart point forms.

The inherent danger of using type names is the possibility of "forcing" a specimen into a cultural-historical entity that may be misleading. Rice Lobed points are considered to date to the Early Archaic period based on their association with a radiocarbon date of $8410 \pm 245$ B.P. $(6460 \pm 245$ B.C.) at the Albertson site in northwest Arkansas (Dickson 1991:265). Williams points likely date to part of the Middle and Late Archaic periods (ca. 4000 B.C. to 1000 B.C.) (Suhm and Jclks 1962:259). There is considerable uncertainty concerning whether Palmillas points are a valid type or a variant of Williams points, but they have been found in association with Williams points and should date to the same general time period.

Most prehistoric sites referenced in the archaeological literature have a mixture of Archaic points that are indicative of long time spans and I can find few references to Archaic sites found exclusively on the uplands. Moreover, few sites with discrete assemblages have been documented in East Texas. One of the better known is the Yarbrough site (41VN6), a 1930s WPA excavation project analyzed by LeRoy Johnson in the upper reaches of the Sabine River (Johnson 1962:155-234). Though his LaHarpe aspect is no longer used, the Archaic sites on the Walters farm loosely fit in Period 2, distinguished by mostly expanding stem style dart points and predating the appearance of Gary points in Period 3. However, the Yarbrough site is in a floodplain setting, whereas the Walters Farm sites are located in the uplands. Sites similar to the ones on my place may exist in alluvial settings but I have found no good reference to them. 
At present too little is known about the lengthy Archaic period to come to any good conclusions about the place of the Browning phase in Archaic prehistory. Investigations that may be relevant include the Tankersley Creek site in Titus County, which seems to post-date the Walters Farm sites. Yarbrough points are among the oldest dart points represented there (Young 1981:63-64). The Jake Martin site at Lake O' the Pines had artifacts similar to ones collected at the Walters Farm sites that were identified as Williams or Castroville point types (Davis and Davis 1960: 33-34). Both of these sites, however, represent long time spans with multiple prehistoric occupations. Thurmond's chronological classification of the Middle Archaic (4000-2000 B.C.) includes Palmillas dart points along with the types Edgewood, Ellis, Evans, Lone Oak, Trinity, Yarbrough, and Wesley; and all untyped straight or expanding stem dart points (Thurmond 1990:39).

Hypothetically if Smith County contains 607,853 acres and 32 percent of that area is in similar soil types/settings to my farm, and I had 1 site to every 50 acres, there could potentially be almost 4000 similar sites in Smith County alone. I think these sites are not often noticed because most of them are small and archaeological surveys do not usually focus on these upland settings. Fortunately, the less intensive use of these same upland settings leads to many of these Archaic sites having single components. Later folks tended more toward settings closer to water sources and it was only about the time of the Middle Caddo period (ca. A.D. 1200-1400) that there is a renewed use of these uplands; even then, sites are found primarily on toe slopes and around the upland margins. It was not until the mid $-19^{\text {th }}$ century that there is evidence again of human activity on these uplands.

Of the six prehistoric sites I have recorded on my 300 acres, two are Paleoindian in age and the remaining four are Middle Archaic in age. I am including these latter four sites, based on their unique traits, in my newly created Browning phase. The extent and purpose of these sites is limited by fact that only two of the sites have had any test excavations and that was limited to a single $1 \times 1 \mathrm{~m}$ test unit; the amount of surface visibility dictated what is now known about each site.

Another point to keep in mind is that there are no lithic sources in the immediate area of these Browning phase sites other than an occasional chunk of petrified wood. The stone tools left on the sites reflect a movement of materials that are non-local in origin, in this case probably through the movement of people since Archaic folks are considered mobile hunter/gathers. Some form of trade may also account for the occurrence of tools made from non-local lithic raw materials. These upland sites in this part of Smith County generally have more tools than lithic debris, and that debris consists mostly of retouch or pressure flakes indicative of tool maintenance, not tool manufacture. I have observed sites in similar upland settings in Cherokee County, some 50 miles to the south, that have abundant flakes of mostly fine-grained cherts, and perhaps these sites are closer to the source of the fine-grained chert raw materials present on Browning phase and other Archaic sites. It is important to locate and map these raw material sources, if indeed they do occur in East Texas. 


\section{Two Palcoindian Sites}

The two Paleoindian sites (No. 1 and 2 on Figure 3) on the Walters Farm are represented by a single Clovis point at each site. This is not unusual for Clovis sites, as most of them in Fast Texas consist of a single point; even well investigated sites do not have large collections of Paleoindian artifacts (see Story et al. 1990:178) The point from Site 1 was $60.5 \mathrm{~mm}$ in maximum length, $29.6 \mathrm{~mm}$ in maximum width, and $7 \mathrm{~mm}$ in maximum thickness. It had fluting scars on both sides $(32.5 \mathrm{~mm}$ long and $15 \mathrm{~mm}$ wide on one side and $20 \mathrm{~mm}$ long and $16.6 \mathrm{~mm}$ wide on the opposite side). The base and edges of the point were ground and it was made from a fine-grained light gray quartzite (Figure 4).

The point from Site 2 (tip missing) had an impact fracture at the point of hafting and a heat-induced pot lid on one surface of the impact fracture, indicating the pot lid occurred after breaking. Length from the base to the impact fracture was $33.8 \mathrm{~mm}$, the base width was $25.6 \mathrm{~mm}$, and the maximum thickness was $6.9 \mathrm{~mm}$. Fluting scars on one side measured $10.2 \mathrm{~mm}$ long (ending in the hinge fracture), and the flute scar on the opposite side was $9.1 \mathrm{~mm}$ long. The base and basal edges are ground and the point is made from a gray chert with red impurities (Figure 5).

\section{Four Browning Phase Sites}

Site 3 represents the most extensive area in terms of size and density of artifacts. When I originally reported Site $3 \mathrm{I}$ also included the area marked as $3 \mathrm{~A}$ where I also collected dart points and ground stone tools (see Figure 3). In retrospect this area should have been designated a separate site. Site 3 proper is located on a convex hill in front of my house and portions of the site were extensively farmed for several years, affording plenty of opportunities to surface collect. The head cut of the main drainage on the farm begins just north of Site 4 (see Figure 3). I collected numerous artifacts from Site 3, all uncontrolled surface finds, except for those artifacts recovered from a single $1 \times 1 \mathrm{~m}$ test unit: one dart point fragment from $0-10 \mathrm{~cm}$ bs and two lithic flakes from $10-20 \mathrm{~cm}$ bs.

The profile of this unit (Figure 6) also reveals one major problem in trying to detect any stratigraphy in these upland sites. There is just not much soil left on these stable to degrading landforms. Instead, most of the archaeology is "pancaked" together in a thin zone usually resting on a strong Bt horizon. It would be very interesting to know the time depth of the prehistoric occupation at Site 3 but radiocarbon samples do not exist because the combination of acidic soils, abundant rainfall, and high temperatures has created poor organic preservation.

Site 3 covers an area measuring approximately $50 \times 50 \mathrm{~m}$ or 2500 square meters. It is hard to imagine groups of people returning to this exact spot for centuries when it is so similar to surrounding upland settings. Although unable to prove it, I believe that the prehistoric occupation at Site 3 represents a relatively short period of time. The dart points 


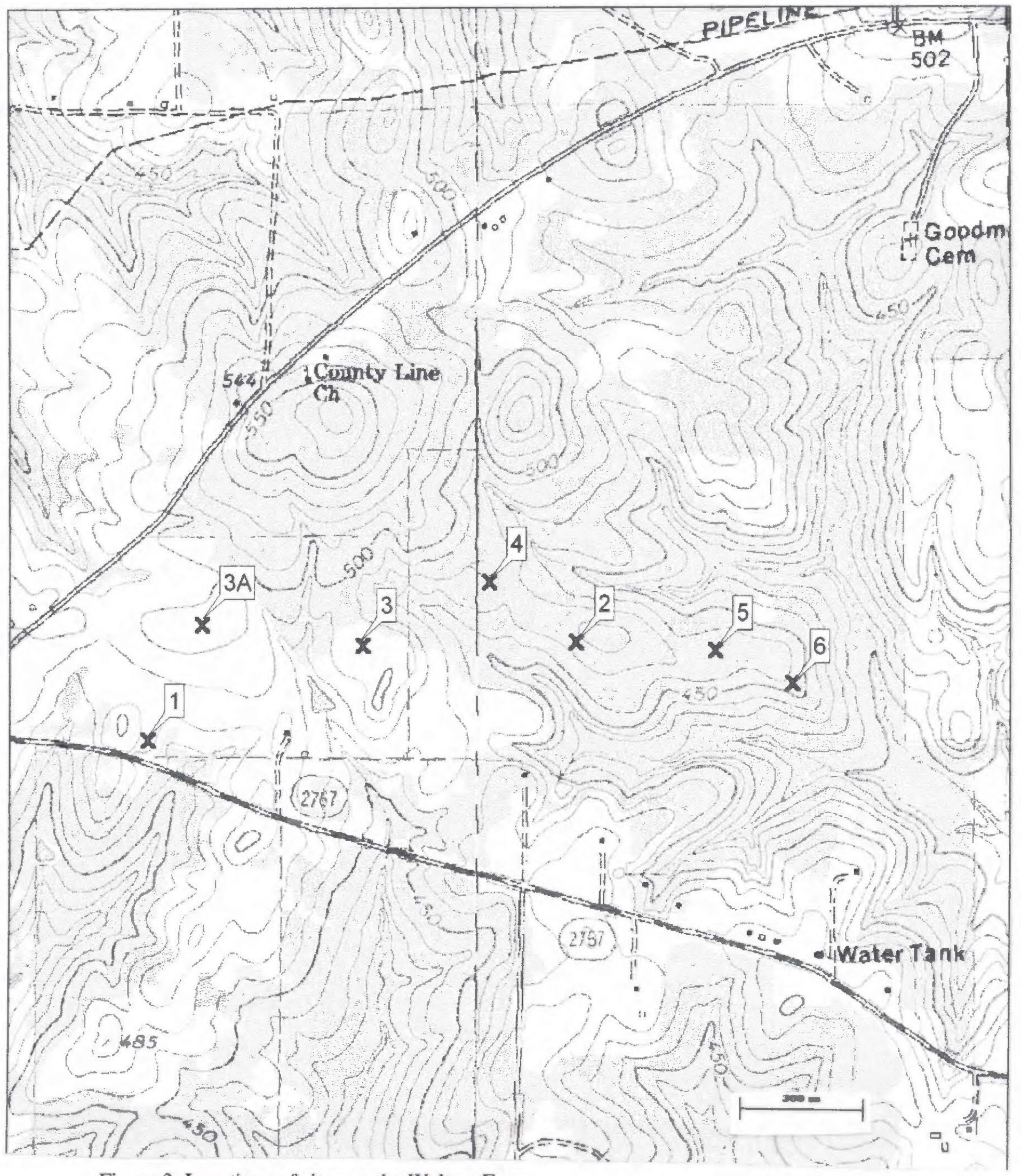

Figure 3. Locations of sites on the Walters Farm. 


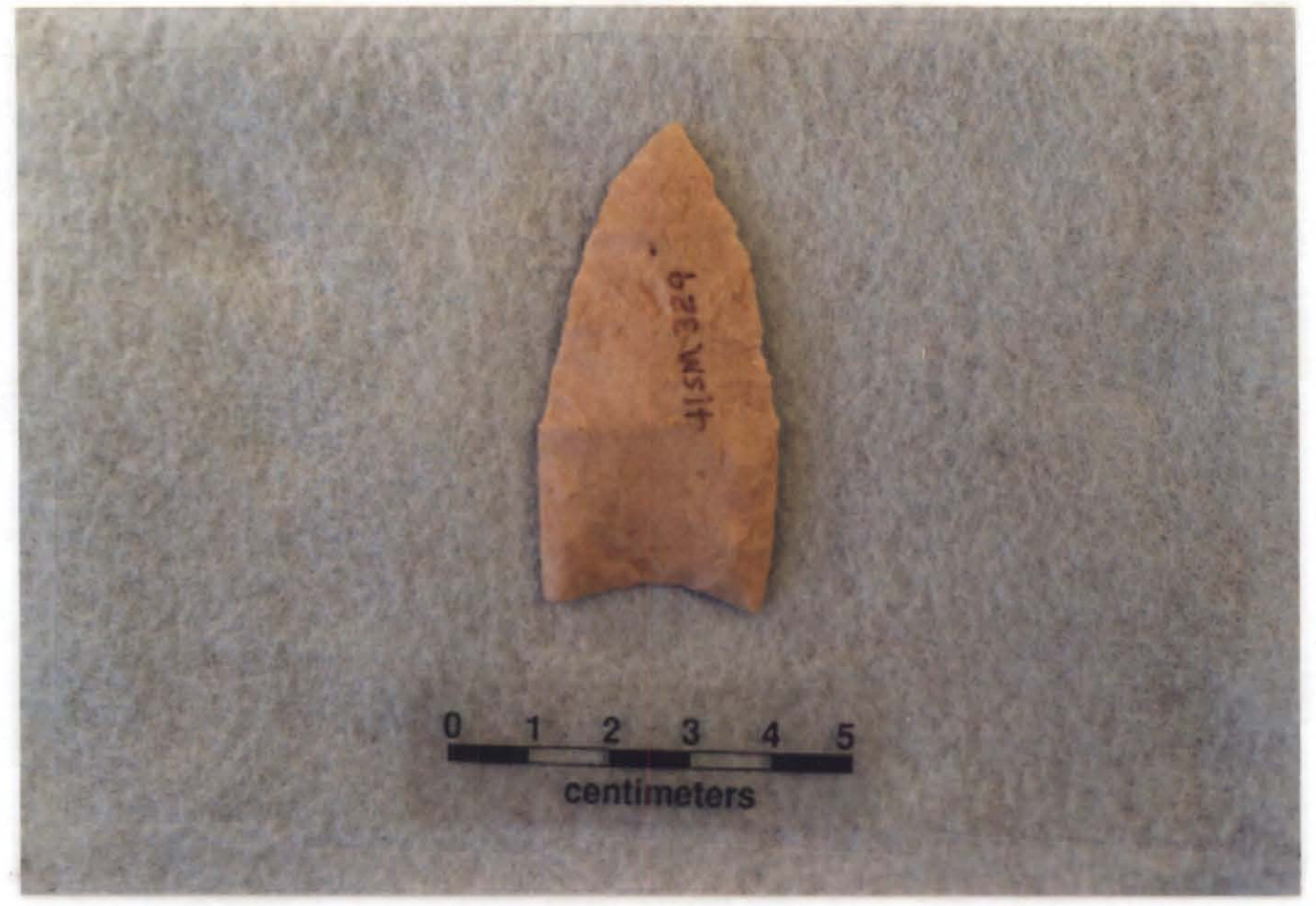

Figure 4. Clovis point from Site 1.

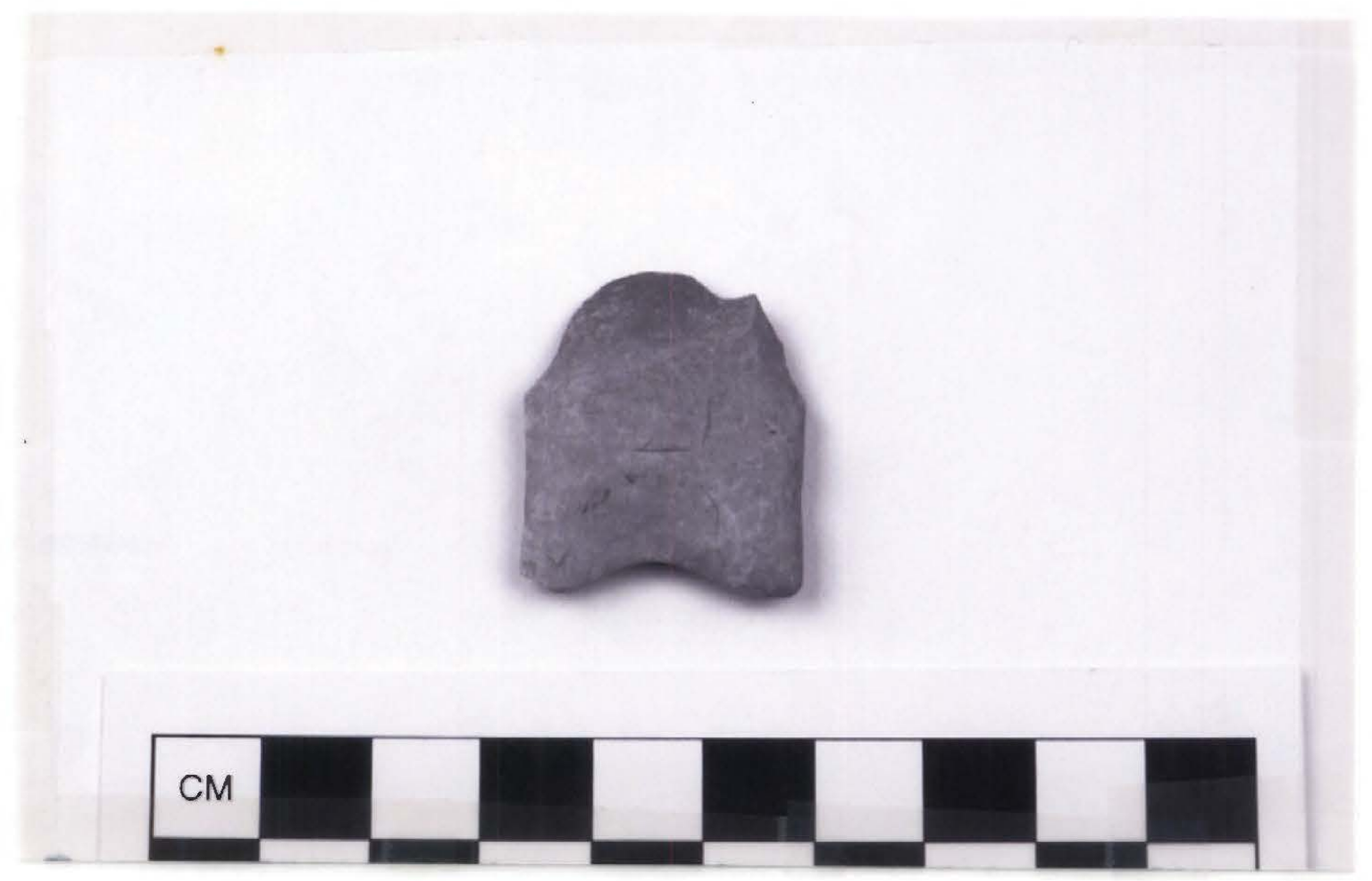

Figure 5. Clovis point from Site 2. 


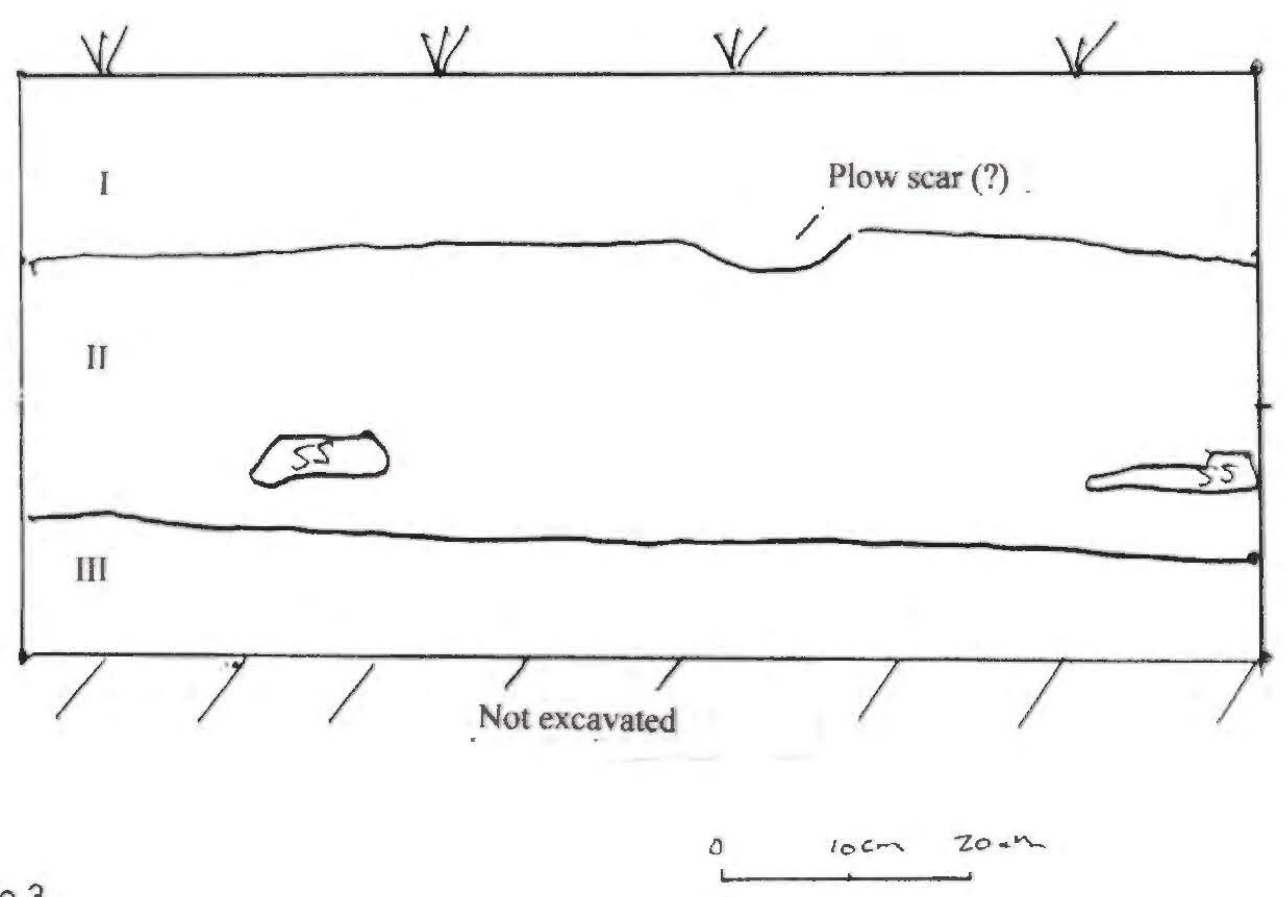

Site 3

U. 1, South Wall Profile

Zone I Dark yellowish-brown sandy loam (10YR4/6). 2000+ sandstone/ironore gravels. Zone II Yellowish-brown sandy loam (10YR5/6). 4000+ sandstone/ironore gravels/cobbles. Zone III Red sandy clay (2.5YR4/8)

Level 11 dart point fragment

Level 22 lithic debris

Figure 6. South wall profile, Unit 1, Site 3.

are consistent morphologically and stylistically. There are nine large dart points with expanding bases (Figure 7), all made from cherts, are well flaked, and uniformly thin. There are 10 dart points that mostly have square bases (Figure 8). All are made from cherts except one of white novaculite (Figure 8c) and another of petrified wood (Figure $8 \mathrm{~g}$ ). Other dart points from Site 3 have lobed/incurved bases similar to the Rice Lobed type (Figure 9).

There were also a number of ground stone tools collected at Site 3, including manos and cup stones (nutting stones) made from ferruginous sandstone (Figure 10). Figure 11 illustrates the front view of a hematite cup stone, while there are also hematite manos in the collection (Figure 12). These extremely fine polished tools may be more than just tools but almost works-of-art. The material and workmanship is very similar to hematite grooved axes that are also found in East Texas, suggesting they may be part of the same tool kit. 


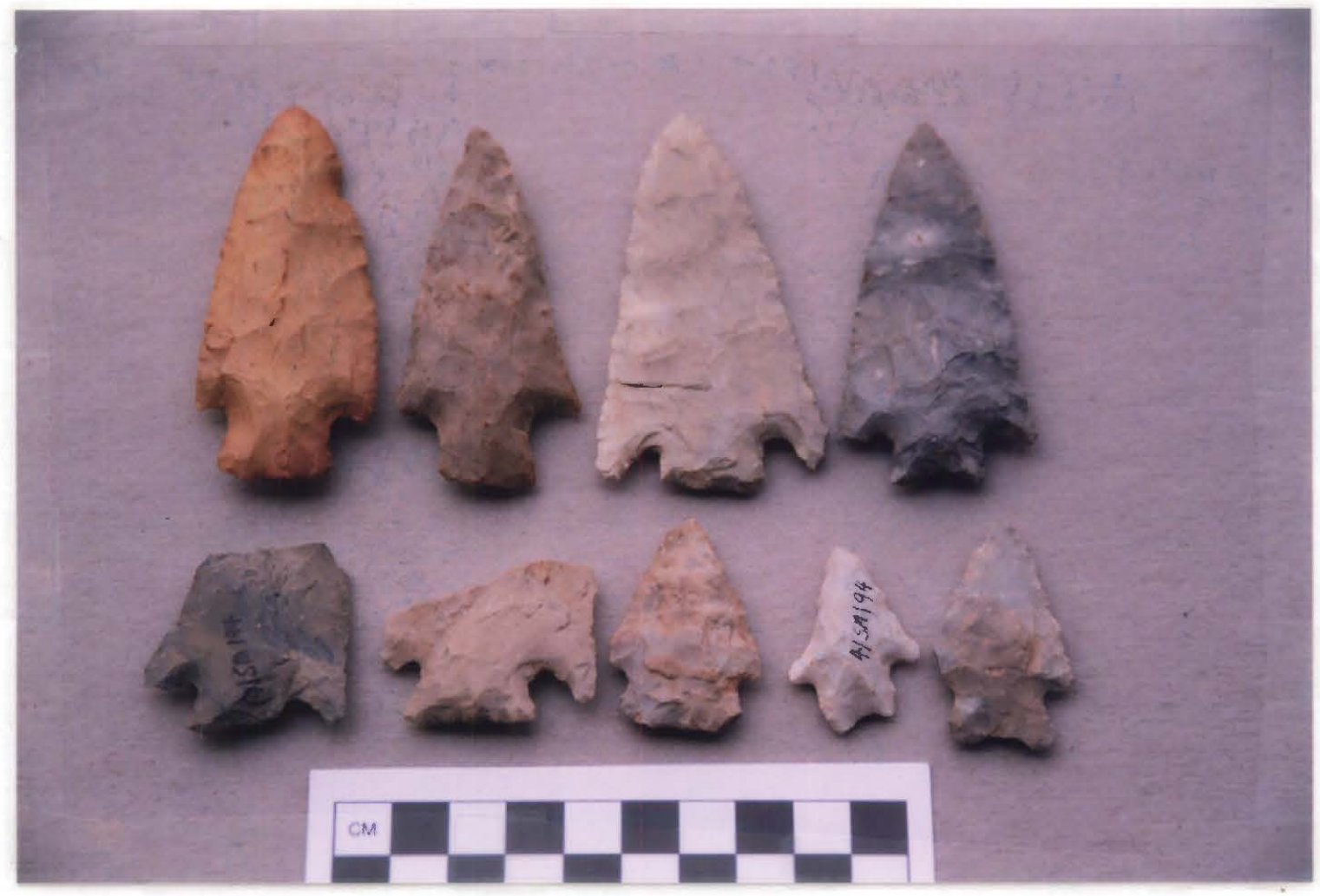

Figure 7. Expanding stem dart points from Site 3.

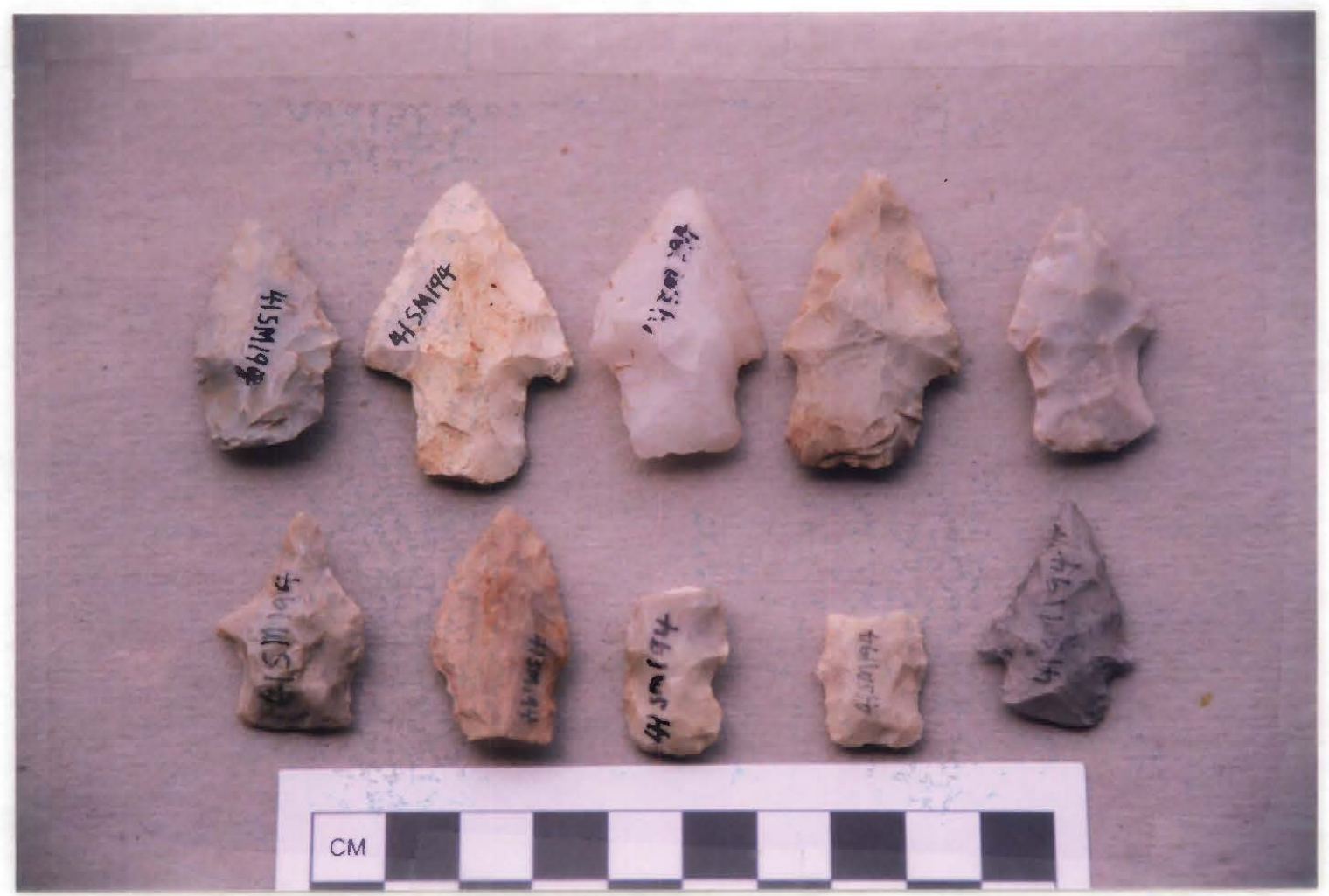

Figure 8. Square base dart points from Site 3. 


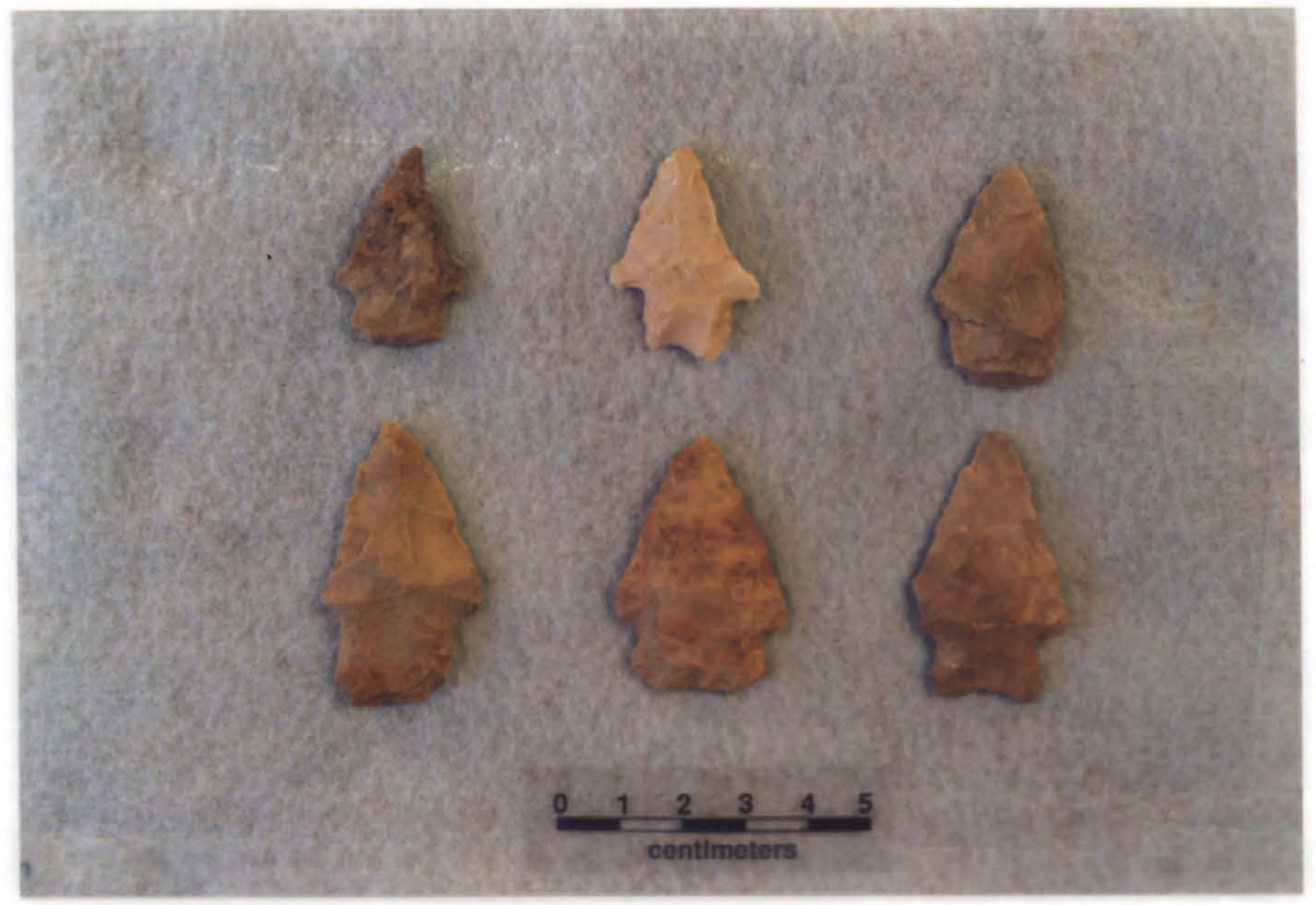

Figure 9. Dart points from Site 3 with lobed/incurved bases,

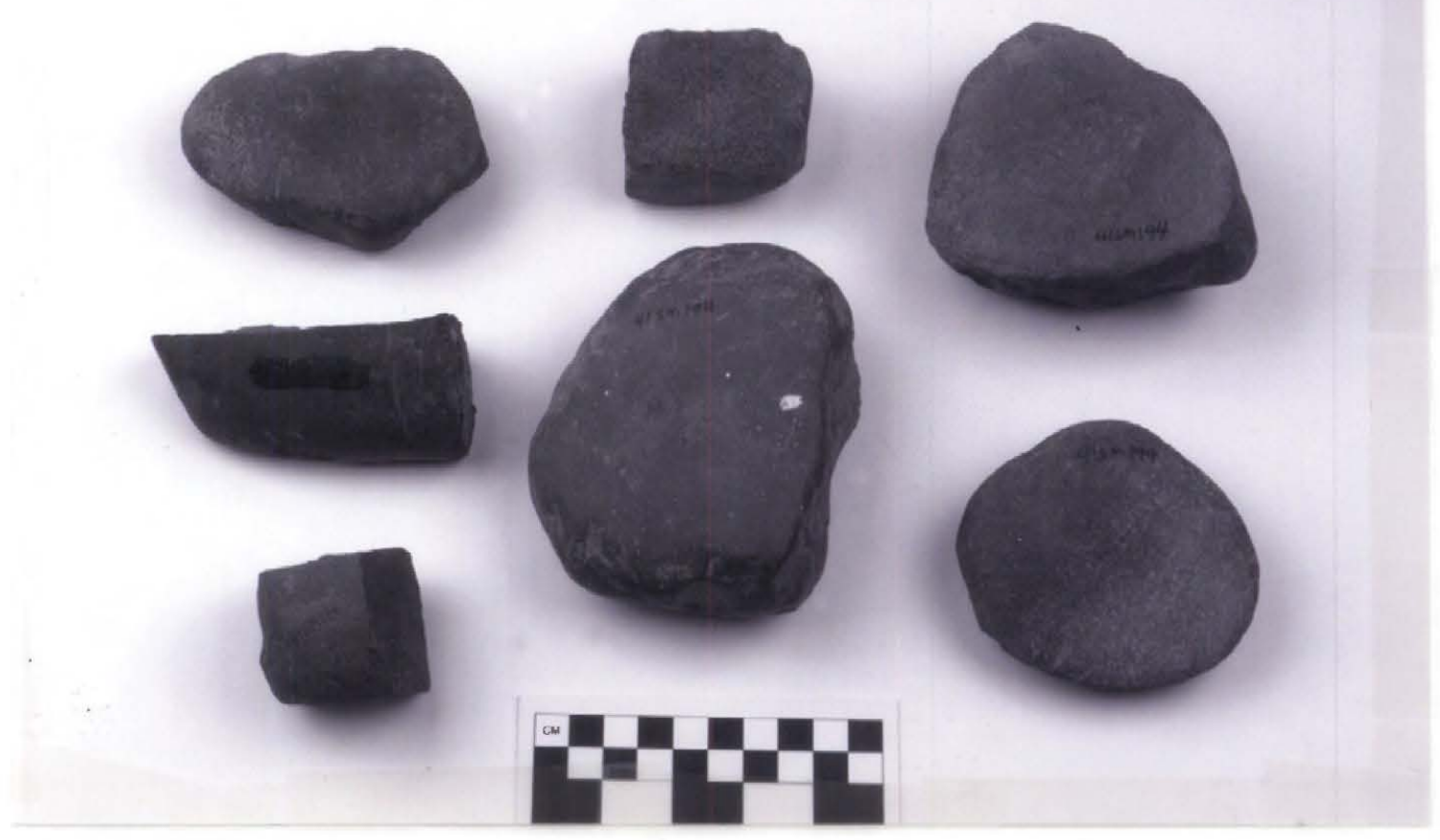

Figure 10. Manos and nutting stones made of ferruginous sandstone from Site 3. 


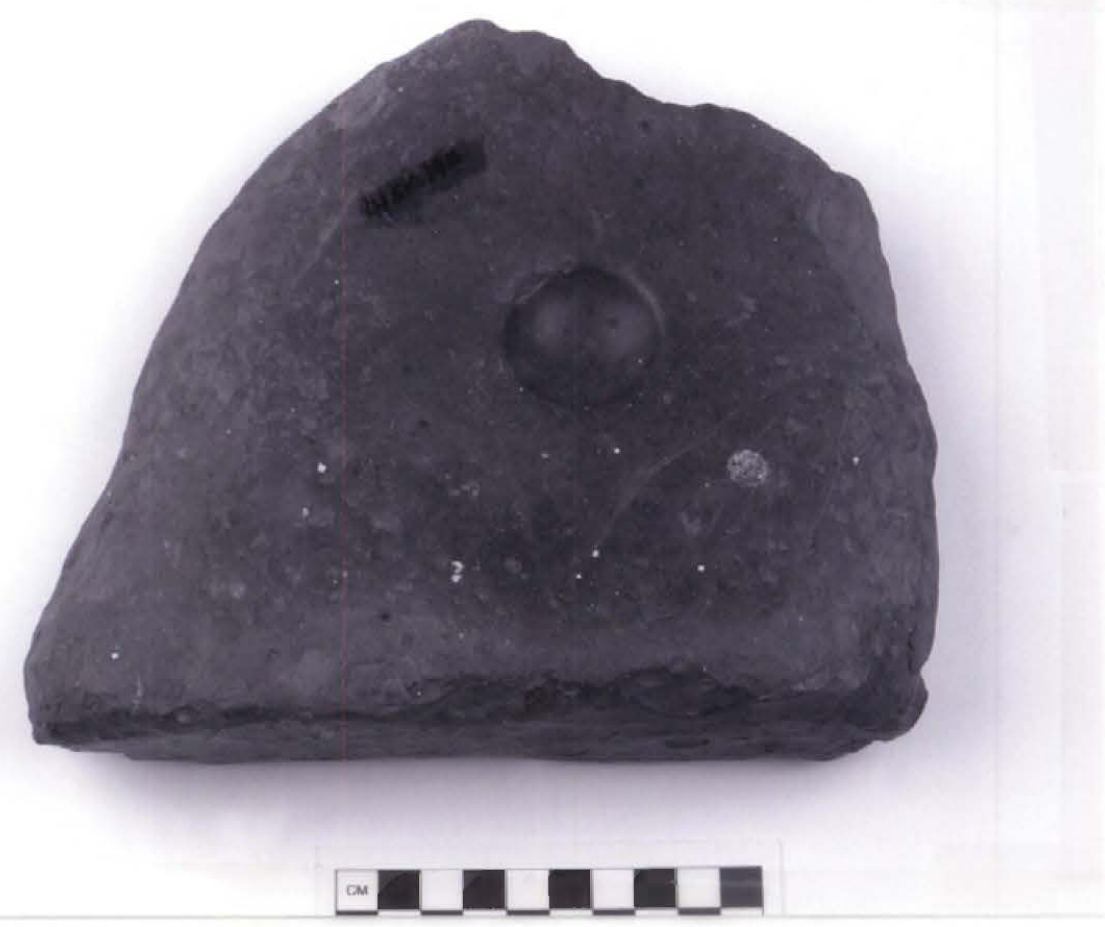

Figure 11. Hematite cup stone from Site 3.

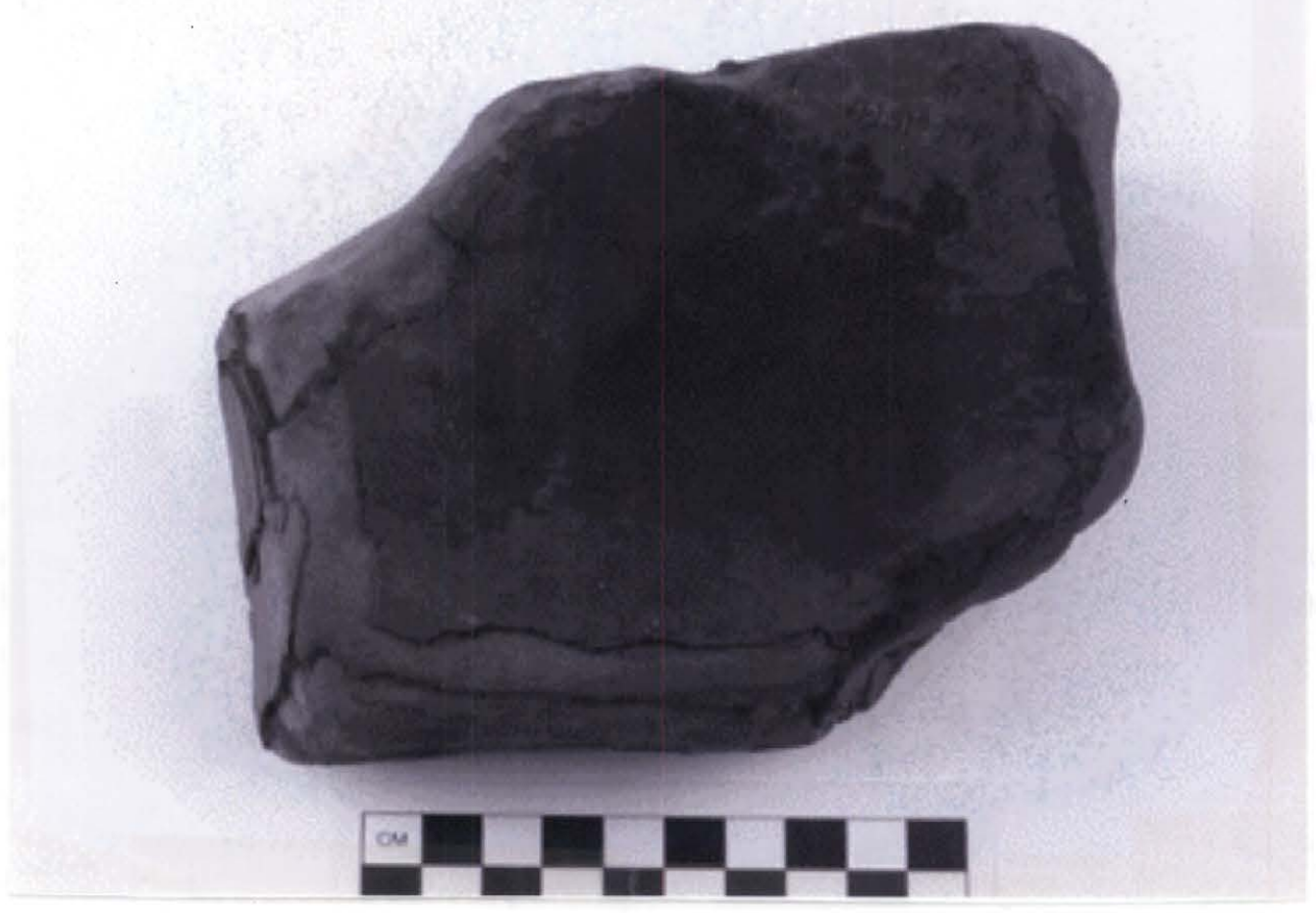

Figure 12. Hematite mano from Site 3. 
The abundance of ground stone tools at Site 3 indicate that plant processing played an important role in Middle Archaic subsistence strategies in addition to hunting. Flakes were observed at Site 3, mostly secondary and thinning flakes, indicating that tool maintenance took place, but probably not tool manufacture. In summary, Site 3 represents a game procurement area as indicated by the large number of dart points found there but also an area where plant remains were processed as evidenced by the number of ground stone tools that are present in the tool assemblage.

Site 4 is represented by a large square-stemmed dart point made from pink novaculite (Figure 13). The point was $62.6 \mathrm{~mm}$ in length, $35.0 \mathrm{~mm}$ wide, and $9.7 \mathrm{~mm}$ thick. Also found at this location was a sandstone mano $(20 \times 14 \times 5 \mathrm{~cm}$ in length, width, and thickness) with a ground concave surface on one side. The only surface exposure at this location is a narrow field road.

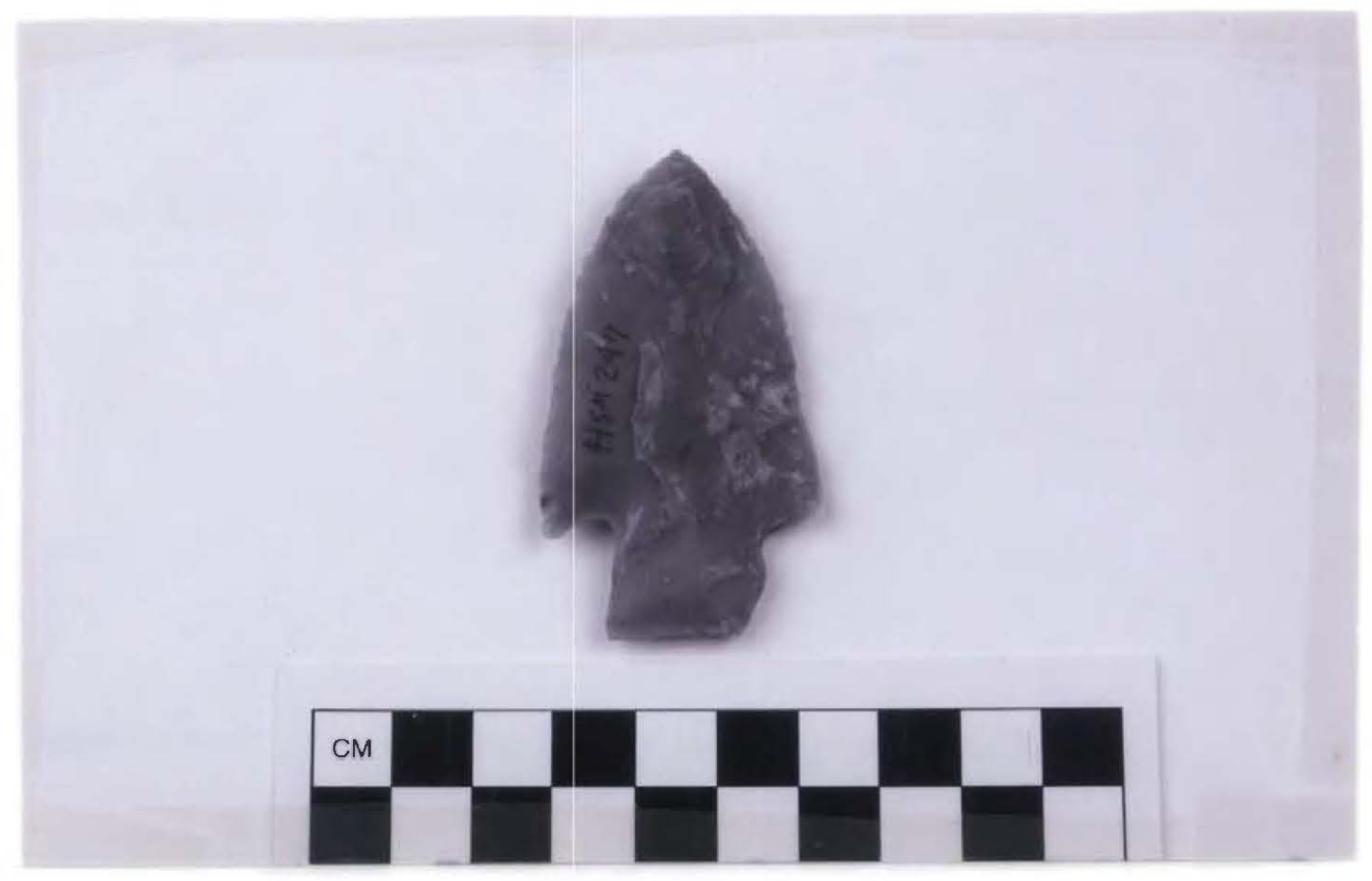

Figure 13. Novaculite square-stemmed dart point from Site 4.

Site 5 is in a small area exposed by a logging road where a square-stemmed dart point and chert core was found on the surface. This location is on the top of a ridge (see Figure 3) and the soils on the landform are shallow. The dart point (Figure 14) was made from tan chert and had the tip missing from an impact fracture. The small core ( $3.5 \times 2.5 \mathrm{~cm}$ in length and width) is a light brown chert with a light gray cortex, and two flakes were removed from one side and one was removed from the opposite side. 


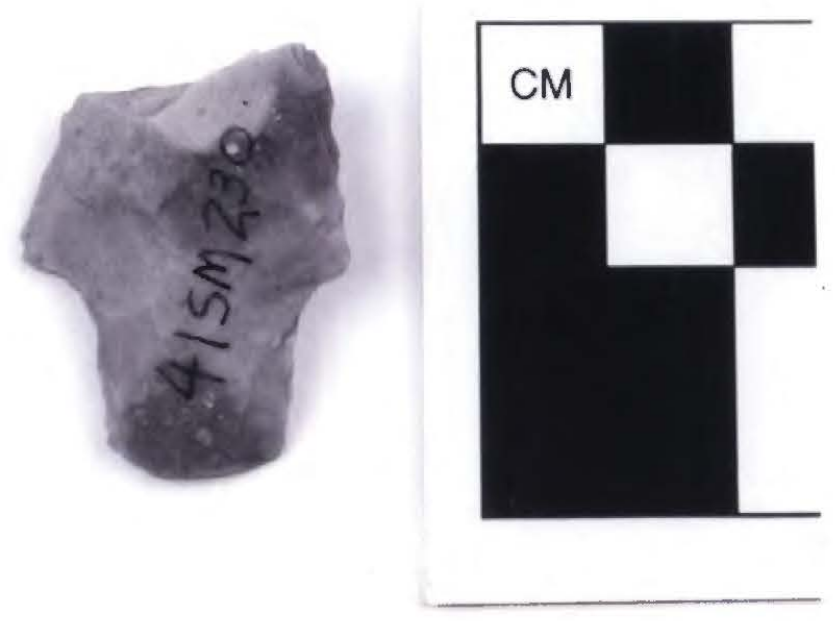

Figure 14. Square-stemmed chert dart point from Site 5.

Site 6 is on the far east side of the farm and at the end of a long ridge that ends at the confluence of two small drainages (see Figure 3). Soils are very shallow, with a red sandy clay exposed at $15 \mathrm{~cm}$ bs in a $1 \times 1 \mathrm{~m}$ unit (Figure 15). There was better exposure at this spot, and the site area covers approximately 2500 square meters where lithic flakes, dart points, and ground stone tools were collected.

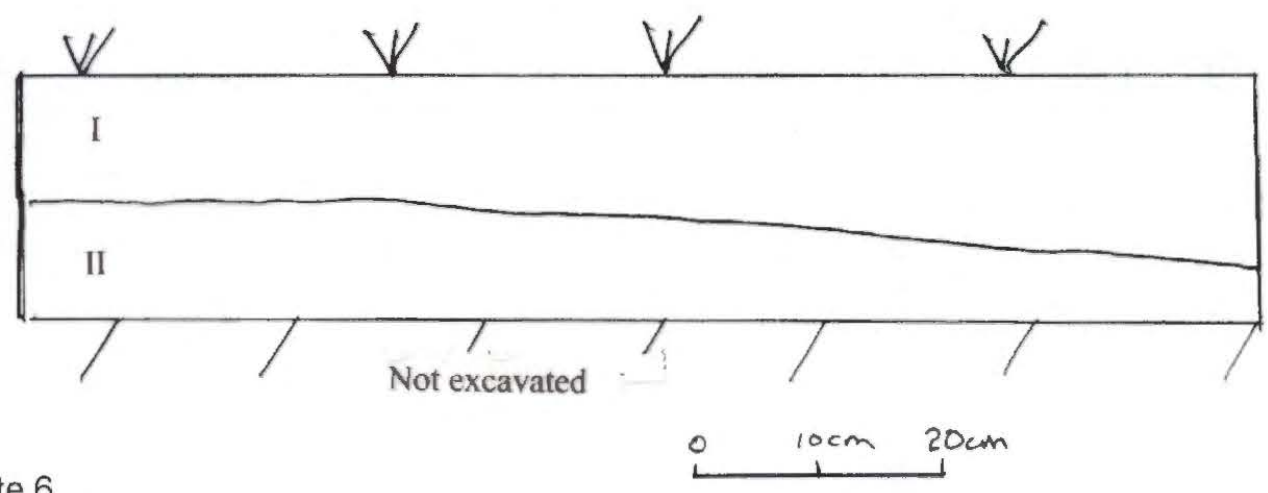

Site 6

U. 1, West Wall Profile

Zone 1 Yellowish-brown sandy loam (10YR5/6). 1000+ sandstone/ironore gravels. Zone II Red sandy clay (2.5YR4/8)

Level $11 \mathrm{GS}$ fragment

Figure 15. Site 6, Unit 1 profile, west wall. 
Artifacts included a small, crude gray quartzite square-stemmed dart point (3.5 $\mathrm{cm}$ in length, $2.0 \mathrm{~cm}$ wide, and $0.75 \mathrm{~cm}$ thick); a tan chert dart point mid-section; a gray chert expanding stem dart point base; a red quartzite biface tip; and a small heavily reworked pink novaculite San Patrice-like point. Flake tools include two square gray chert unifaces with retouch on three sides and one gray chert tool with retouch on one edge. Flakes observed were mostly from gray and tan cherts and were interior or retouch flakes from tool sharpening or maintenance. Ferruginous sandstone ground stone tools include one tool with shallow ground depressions on each side and one mano (11 x 7 x 4 $\mathrm{cm}$ in length, width, and thickness) that was smoothed on both sides.

\section{Examples of other Browning Phase sites in the area}

On the farm adjacent to the Walters farm at the Lost Dog site (41SM327), a large square-stemmed dart point was collected from an upland setting (Figure 16). Sam Whiteside, a Smith County avocational archeologist and longtime Texas Archeological Society member, listed the Atkinson site (41SM339) in his journal as being an Archaic site "on a high hill a long distance from water." Several of the dart points he recovered from the Atkinson site (Figure 17) are similar to those from the Walters Farm. This site is but a few miles from the Walters Farm on an upland landform with similar soils. A few miles further away, again on an upland setting, at the Gin site (41SM344), a number of chert tools and large square and expanding stem dart points were collected from a Middle to Late Archaic occupation.

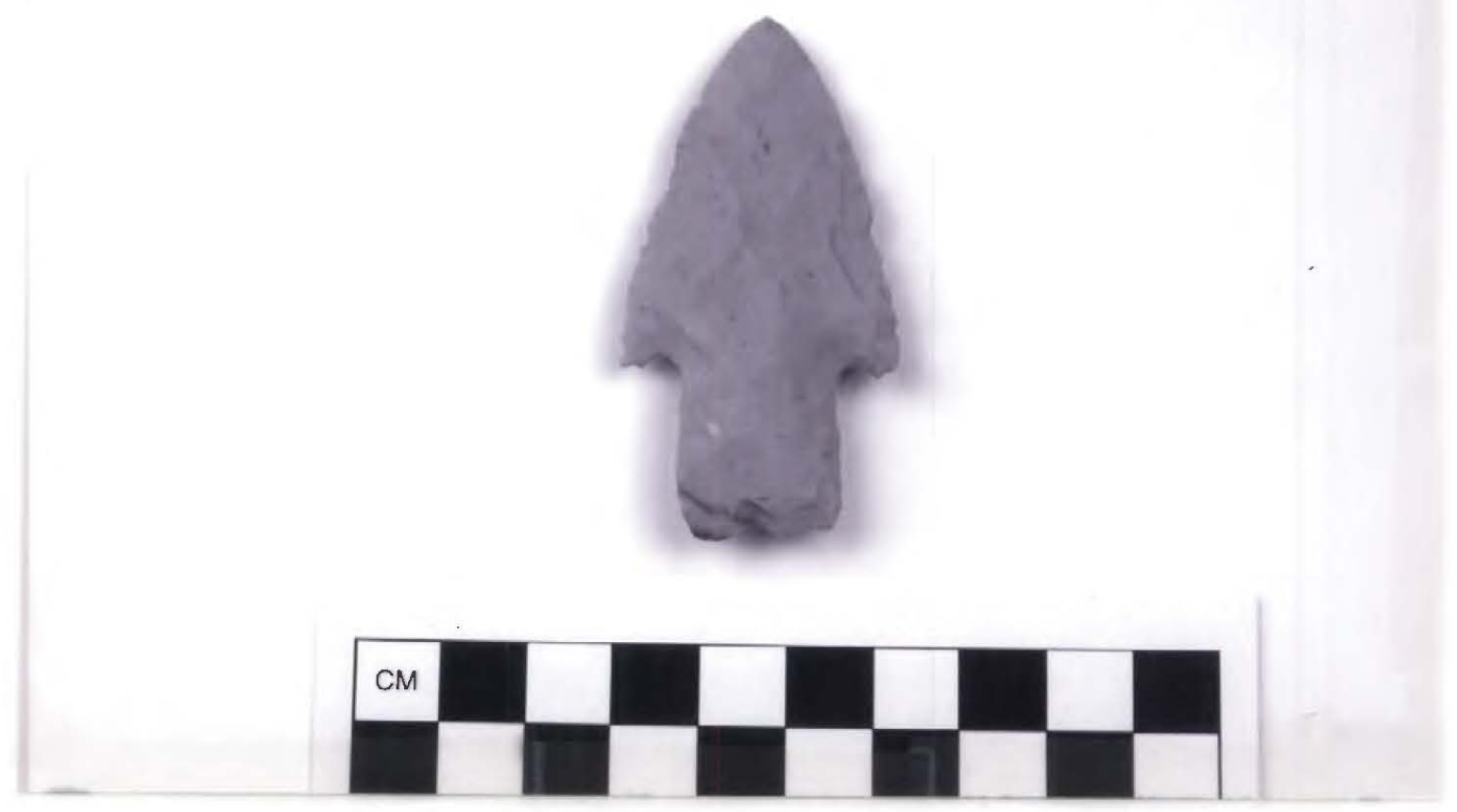

Figure 16. Square-stemmed dart point from the Lost Dog site (41SM327). 


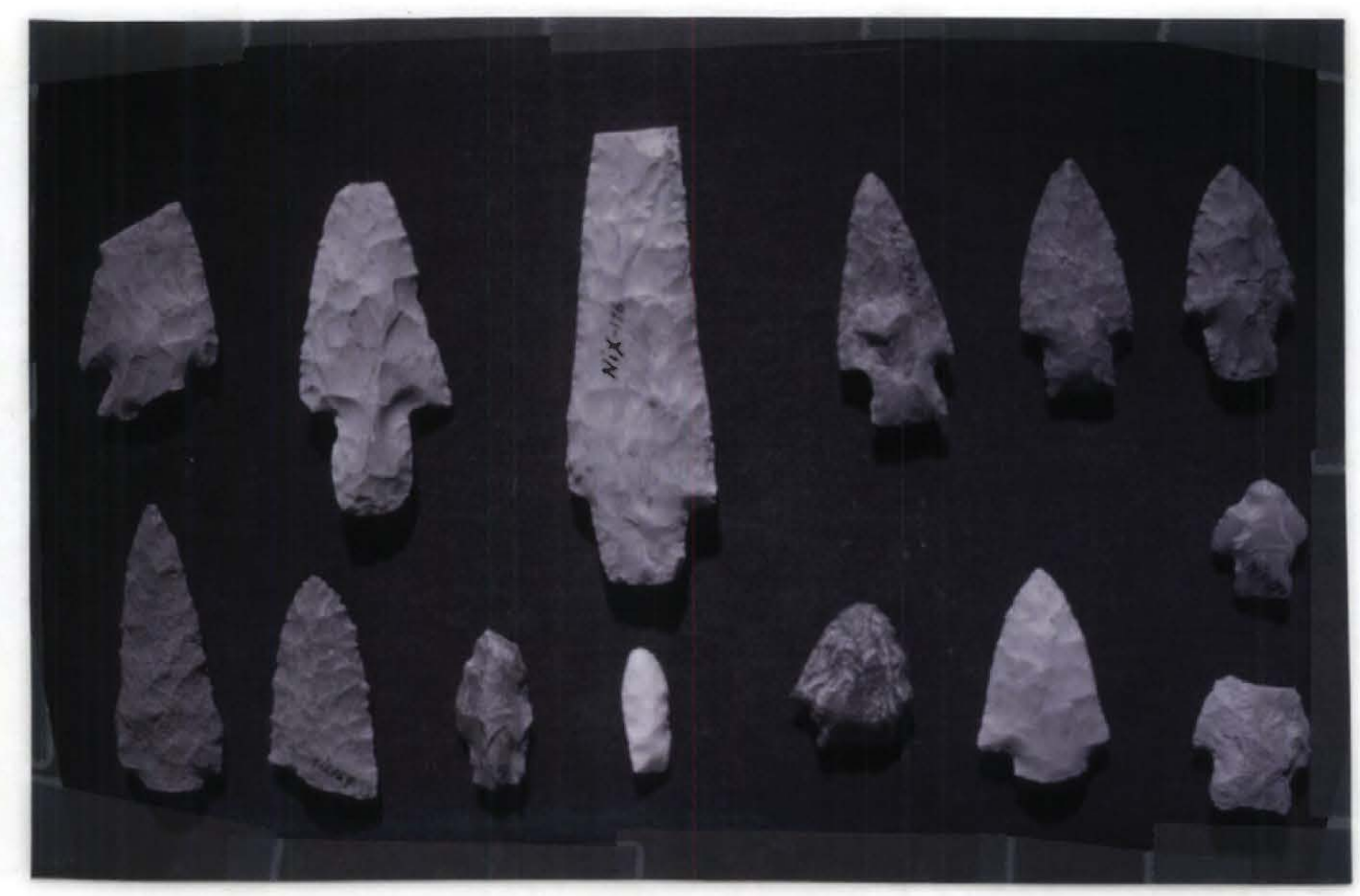

Figure 17. Dart points from the Atkinson site (41SM339).

\section{Conclusions}

Can we explain what the Browning Phase folks were doing on these upland settings? It is obvious they were hunting and plant gathering/processing was also important. They had access to good quality lithic raw materials, either through trade or as a result of their mobile hunting and gathering lifestyle. Whether the sites of the Browning phase can be demonstrated to be part of a unique highland-oriented prehistoric culture in East Texas will depend on future research in the area.

\section{References Cited}

Davis, W. A. and E. M. Davis

1960 The Jake Martin Site, Archaeology Series, No. 3. Department of Anthropology, The University of Texas at Austin.

Dickson, D.

1991 The Albertson Site: A Deeply and Clearly Stratified Ozark Bluff Shelter. Research Series No. 41. Arkansas Archeological Survey, Fayetteville. 